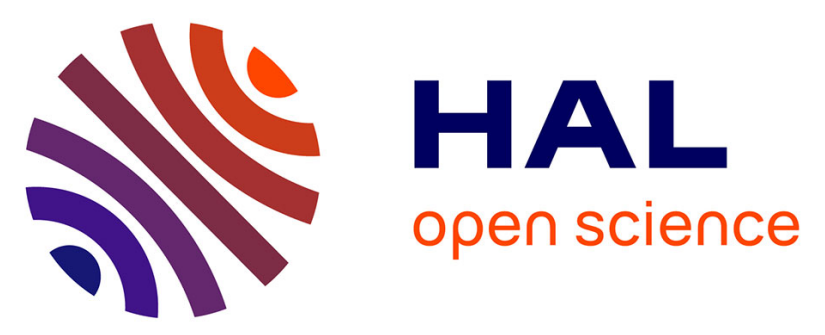

\title{
The role of urban structures in the distribution of wasteland flora in the Greater Paris Area, France
}

Audrey Muratet, Nathalie Machon, Frédéric Jiguet, Jacques Moret, Emmanuelle Porcher

\section{- To cite this version:}

Audrey Muratet, Nathalie Machon, Frédéric Jiguet, Jacques Moret, Emmanuelle Porcher. The role of urban structures in the distribution of wasteland flora in the Greater Paris Area, France. Ecosystems, 2007, 10 (4), pp.661-671. 10.1007/s10021-007-9047-6 . mnhn-02265425

\section{HAL Id: mnhn-02265425}

\section{https://hal-mnhn.archives-ouvertes.fr/mnhn-02265425}

Submitted on 9 Aug 2019

HAL is a multi-disciplinary open access archive for the deposit and dissemination of scientific research documents, whether they are published or not. The documents may come from teaching and research institutions in France or abroad, or from public or private research centers.
L'archive ouverte pluridisciplinaire HAL, est destinée au dépôt et à la diffusion de documents scientifiques de niveau recherche, publiés ou non, émanant des établissements d'enseignement et de recherche français ou étrangers, des laboratoires publics ou privés. 


\section{The role of urban structures in the}

\section{distribution of wasteland flora in the}

\section{Greater Paris Area, France}

Audrey MURATET ${ }^{1, *}$ - Nathalie MACHON ${ }^{1,2}$ - Frédéric JIGUET ${ }^{2}$ - Jacques MORET ${ }^{1}$ Emmanuelle PORCHER ${ }^{1,2}$

\footnotetext{
${ }^{1}$ Conservatoire botanique national du Bassin parisien, UMS Inventaire et Suivi de la Biodiversité, Muséum national d'Histoire naturelle, 61 rue Buffon F-75005 Paris, France; ${ }^{2}$ UMR 5173, Conservation des Espèces, Restauration et Suivi des Populations, Muséum national d'Histoire naturelle, 61 rue Buffon F-75005 Paris, France; 'Corresponding author. Tel: +33 1 407935 45; fax: +33 1407935 53. E-mail address: muratet@mnhn.fr
} 


\begin{abstract}
Wastelands are likely to host a significant part of urban floristic diversity but have received limited attention because they are not considered interesting green zones. Here, we explore the potential role of wastelands in maintaining urban biodiversity to help define effective urban

5 management plans. We quantified floristic diversity in 98 wasteland sites of Hauts-de-Seine, one of the most densely populated areas in France, and characterized the environmental parameters and spatial distribution of sites to identify some of the factors that influence plant species composition and to explore the impact of urban environment on the floristic interest of wastelands. Their floristic richness represented $58 \%$ of the total richness observed in the whole

10 study area. Site richness depended on site area (the largest sites were the richest) and site age, with a maximum in sites of intermediate age (4 to 13 years). In the largest sites only ( $>2500$ $\mathrm{m}^{2}$ ), the floristic distance among sites was positively correlated with geographic distance, which suggests that migration of species among large sites partly controls local floristic composition. In contrast, the environmental distance among sites was not correlated with

15 floristic distance. Finally, we showed that the presence of collective and individual dwellings within $200 \mathrm{~m}$ of a wasteland decreased its floristic rarity, whereas the presence of rivers or ponds increased it. We derive several recommendations to optimize the management of wastelands with respect to conservation of urban biodiversity.
\end{abstract}




\section{Introduction}

Conservation policies in urban zones usually target relicts of natural landscapes, such as wetlands or woodlands. In contrast, artificial urban habitats are not considered interesting green zones by most city-dwellers (Sukopp and Werner 1987). In particular, wastelands,

5 defined as abandoned lands where plant species grow without human control, are frequently neglected in conservation plans. However, despite their often negative image, they can be of importance due to their high floristic diversity (Maurer and others 2000; Zerbe and others 2003; Herbst and Herbst 2006). The presence of wastelands in cities may thus contribute significantly to the total biodiversity in urban areas, although the extent of their role is poorly

10 documented. Thus, studying wastelands is of primary concern to assess their role in maintaining urban biodiversity and to define effective urban management plans.

Although the high floristic diversity of wastelands is now relatively well documented, very little is known regarding the mechanisms that control the distribution of flora in this habitat; this fundamental information should be accounted for in conservation strategies. As in many

15 human-disturbed habitats, species composition in urban wastelands is likely influenced by (1) biotic and abiotic environmental conditions (soil, light, humidity, interspecific competition...), (2) the pool of species able to colonize from neighboring (wasteland or non-wasteland) sites, (3) the barriers preventing pollen/seed flow among sites, and (4) the frequency and intensity of human-induced disturbance. Wastelands are subject to various development pressures

20 (Harrison and Davies 2002), and their life span is highly variable but generally short. In the short to mid-term, wastelands are partly protected from human-induced disturbance by their negative image, which may favor biodiversity. However, wastelands can also be short-lived habitats whose life span is defined by the necessity to construct new buildings or parks. The 
succession of local extinctions and colonizations of newly vacant sites from neighboring sites may thus create metacommunity dynamics in urban wastelands. Depending on which factors exert the strongest influence, plant species composition can be spatially autocorrelated (e.g. if among-site dispersal is possible but limited in space) or completely patchy (e.g. with little 5 among-sites dispersal, strong effect of local environments, or influence of local human pressure only). Unraveling the relative importance of biological interactions, dispersal limitation, and environmental determinism in inducing differences in species composition among sites is a central issue in plant ecology (Hurtt and Pacala 1995; Whitfield 2002).

In the present study, we quantify floristic diversity in ca. 100 wastelands of the Greater Paris 10 area, and for the first time explore the role of some of the human and environmental factors controlling their floristic composition, to evaluate the consequences for the conservation of urban biodiversity. Wasteland floristic diversity was measured via species richness, species rarity and indigeneity. We described the characteristics of wasteland sites (spatial distribution, floristic diversity, age, and area) in one of the most urbanized zones of France and used data 15 from the Land Use Pattern to address the following questions:

(1) What is the influence of the abiotic environment on the floristic diversity of wastelands? To address this, we compared matrices of floristic distances to matrices of environmental distances between wasteland sites.

(2) Does migration among wastelands play a role in maintaining floristic diversity? To address this, we compared matrices of floristic distances to matrices of geographic distances between wasteland sites.

(3) Do urban structures surrounding wasteland sites impact floristic diversity? To address this, we studied the relationship between the floristic diversity of wasteland sites and the presence of various urban structures around the sites, as inferred from the Land Use Pattern. 


\section{Material and methods}

\section{$\underline{\text { Study area }}$}

Wasteland floristic diversity was studied in Hauts-de-Seine (France), a crescent-shaped administrative department $\left(48^{\circ} 50^{\prime} \mathrm{N} ; 2^{\circ} 14^{\prime} \mathrm{E}\right)$ located in the heart of the Greater Paris area

5 (which represents a total of $2720 \mathrm{~km}^{2}$ ). This department is composed of 36 boroughs that cover a total area of $176 \mathrm{~km}^{2}$ (Figure 1). The climate is oceanic with continental trends: the mean annual temperature is $11.7^{\circ} \mathrm{C}$ with a thermal amplitude of $16^{\circ} \mathrm{C}$ and an average annual rainfall of $641 \mathrm{~mm}$. The department is located between the Beauce Plateau and the Seine River Valley, comprising of a plain, small hills and a plateau. It is one of the most densely inhabited zones of

10 France, with a human density of 8118 inhabit. $/ \mathrm{km}^{2}$ (INSEE 1999) as opposed to 95 inhabit. $/ \mathrm{km}^{2}$ on average in France. The successive Land Use Patterns from 1982 to 2003 were provided by IAURIF (2003). They show, in particular, that built zones have covered about $70 \%$ of the territory for more than 20 years (IAURIF 2003 see Figure 1).

\section{$\underline{\text { Sampling design and inventories }}$}

15 The flora of Hauts-de-Seine was inventoried over all the department, on a total of 986 sites, using a stratified sampling strategy, i.e. the surface of inventoried sites in a given habitat was proportional to the total area occupied by this habitat in the department (see Muratet 2006 for details on site location and sampling methods). Each site was inventoried once between 2001 and 2005, in spring, summer or autumn. During an inventory, we recorded all wild vascular

20 plant species over the whole site area ("global method"), i.e. we dismissed cultivated and ornamental species. Species were classified as "indigenous" or "naturalized" according to a list compiled by professional botanists of the National Botanical Conservatory of the Parisian 
Region (CBNBP). Naturalized species are non-indigenous species that now behave like indigenous species (Richardson and others 2000). Several environmental parameters were also recorded: light exposition, slope, type of parent rock, and site geomorphology.

Among the 986 inventoried sites, 98 were wastelands with areas ranging from 12 to $18263 \mathrm{~m}^{2}$.

5 As mentioned above, wastelands were defined as sites where vegetation management has been more or less temporarily abandoned. In cities, four types of wastelands can be found (1) Wastelands located in building sites and vacant urban areas, corresponding to transitions in land use, (2) Wastelands located in open urban areas, corresponding to irregularly managed plots of gardens, parks, golf courses and sport fields, (3) Wastelands located in built-up areas 10 (dwellings, activities, facilities), corresponding to abandoned industrial plots or to small unused interstices in the built matrix, (4) Wastelands located in subnatural environments (e.g. woods or river banks), corresponding to the disturbed edges of natural zones.

In 13 of these sites, chosen for their accessibility, an alternative method of inventory ("quadrat method") was used in addition to the "global" method to test the accuracy of the 15 latter at producing unbiased estimates of local plant diversity. In the quadrat method, we performed five replicate inventories within each site, using $3 \mathrm{~m} \times 3 \mathrm{~m}$ quadrats that were placed systematically in the field to avoid an observer bias during the choice of quadrat location. We used the CAPTURE program in the Mark software (Rexstad and Burnham 1991) to obtain species richness estimates. The model including heterogeneity effect on species 20 detectability only, $M(h)$, yielded the best fit of data and was retained to analyze the "quadrat method". We found no significant difference between the richness observed via the "global" method and the richness estimated by capture-recapture via the "quadrat" method (Wilcoxon signed-rank test, $P=0.097$ ) although observed richness was generally lower than estimated richness. Therefore, the global method seems to provide an accurate and confidently unbiased 
measure of species richness, and the results we present in the following are derived from this method only.

\section{Geographic information system}

We mapped the distribution of wastelands in Hauts-de-Seine (Figure 1) and calculated their

5 area using a Geographic Information System (MapInfo software, MapInfo Corporation 2004). Additional information regarding wastelands was retrieved from six updates of the Land Use Pattern (LUP), performed in 1982, 1987, 1990, 1994, 1999, and 2003 and provided by IAURIF (2003).

The LUP contains 83 different classes that were grouped into nine major classes for this

10 study (Appendix A). We identified the LUP classes in which wastelands were found. By comparing the different updates of the LUP (Table 1), we could estimate the age of each wasteland site, defined as the number of years during which the site LUP class remained the same. We also identified the LUP classes around each wasteland, to characterize their urban environment.

\section{Data analysis}

\section{Indices of floristic interest}

To study the impact of the urban environment on the floristic interest of wastelands, we used three parameters of floristic interest for a given site: (1) species richness (Rich), the total number of species observed in the site, (2) indigeneity (Ind), the proportion of indigenous

20 (versus naturalized) species and (3) rarity (Rar). For a given species, rarity ( $\operatorname{Rar}_{\mathrm{sp}}$ ) is the fraction of sites (including all habitats) in the department in which the species was not observed. $\operatorname{Rar}_{\mathrm{sp}}$ varies between 0 (the species was observed in all sites) and 985/986 (the 
species was observed in a single site in the department). At the site level, rarity (Rar) is the mean of specific rarity indices over all species observed in the site.

\section{Relationship among floristic, environmental and geographic distances}

5 As site area has a major influence on species richness (see Results), sites were grouped into four quartile area classes to avoid confounding area effects when analyzing the effect of geographic and environmental distances. The geographic distance between two sites was defined as the Euclidean distance between their barycentres. The floristic distance between two sites, $d_{f}$, measuring the difference in species composition, was calculated from the global

10 inventory data via the Jaccard similarity index $s_{f}$ with the $\mathrm{R}$ software (R Development Core Team 2005), using the ADE4 package (Thioulouse and others 1997) as follows:

$$
d_{f}=\sqrt{1-s_{f}}
$$

where $s_{f}$, the fraction of total species found in both sites. The environmental distance between two sites was calculated via the Gower index $s_{e}$, which includes a correction factor for the

15 missing values, using the ADE4 package (Thioulouse and others 1997).

$s_{e}=$ number of environmental parameters with identical values in both sites/(total number of values for all parameters + number of parameters values not found in both sites)

Correlations between floristic distance and geographic or environmental distances were tested with simple and partial Mantel tests based on Pearson correlations using the vegan package

20 from the R software (Oksanen and others 2005).

\section{Impact of urban environment on floristic interest}

We analyzed the variation of floristic interest indices using three ANCOVAs where site richness, indigeneity or rarity was a function of (1) the LUP class in which sites were located,

25 (2) distance from the center of Paris, a good proxy for urbanization intensity (the proportion of 
built-up areas strongly depends on the distance to the center of Paris, linear regression, proportion $=1.18-0.05 \mathrm{x}$ distance, $\left.r^{2}=0.83, \mathrm{P}<0.0001\right)$, (3) site age, (4) season of inventory, (5) all pairwise interactions among these four variables, and (6) simple effects of ecological parameters: parent rock, geomorphology, slope, and exposition. Site area was added

5 as a quantitative covariate in the model. Using a stepwise AIC method, this full model was simplified to retain the most informative model.

We assessed the impact of urbanization patterns around wastelands on their floristic interest by studying the relationships between (1) floristic interest indices (Rich, Ind and Rar) of a wasteland site and (2) variables with a significant effect retained from the ANCOVA above,

10 plus the proportion of area occupied by the 9 LUP classes within a $200 \mathrm{~m}$ buffer around the site center. The LUP class area proportions were obtained using the MapInfo software (MapInfo Corporation 2004) and Arcsin-root transformed to approach normality. The $200 \mathrm{~m}$ radius was identified in a former study as the best radius fitting floristic variation in Hauts-de-Seine to the proportion of the different LUP classes (Muratet 2006). Hierarchical partitioning (Walsh and

15 McNally 2004) were conducted on $r^{2}$ values to isolate parameters with a significant independent effect on the site floristic interest and to correct for multicollinearity (McNally 2002). A randomization (500 times) permitted the segregation of the significant independent effects on the Rich, Ind and Rar indices.

\section{Results}

\section{Description of studied wastelands}

The 98 studied wastelands were distributed over the whole area of the Hauts-de-Seine department (Figure 1) and were observed in each of the nine LUP classes (Figure 2). However, 
they were more frequently located in the "building and vacant area" (BUILVAC) class (28\%), corresponding to transitions in land use yielding temporary abandoned plots and in the "open and rural areas" (OPENRUR) class (25\%), i.e. irregularly managed plots of horticulture, orchards, gardens, parks, golf courses and sport fields. Wastelands in the built (ACTI, COLL,

5 FACI, INDI and TRAN) classes corresponded to abandoned industrial plots or to small unused interstices in the built matrix. There were very few wastelands in "natural environments » (WATE and WOOD) (2\%).

In contrast to what we expected for frequently disturbed habitats, wastelands were generally old, with $66 \%$ of sites older than 21 years. The oldest ( $>21$ years) wastelands were

10 significantly smaller than sites of intermediate age (between 4 and 21 years) $\left(r^{2}=0.21\right.$, $P=0.0002$, Table 1).

\section{$\underline{\text { Floristic results }}$}

We recorded a total of 365 vascular plant species in the Hauts-de-Seine wastelands, which corresponds to $58 \%$ of the total species richness recorded over the whole department. The mean richness was 39 species per site, varying between 5 and 92 species.

Among the 365 species, nine were found in more than half of the sites (Artemisia vulgaris L., Cirsium arvense (L.) Scop., Plantago lanceolata L., Picris hieracioides L., Urtica dioica L., Taraxacum campylodes G.E.Haglund, Calystegia sepium (L.) R.Br., Rumex obtusifolius L., and Buddleja davidii Franch.). All are very common species that are also frequently found in

20 other habitats of the study area. These species are perennial species that prefer the nutrient rich soils generally found in urban zones.

A total of 109 species among 365 were observed only once in wastelands but none of them is protected. These species could be rare species at the department scale (e.g. Lythrum hyssopifolia L., Euphorbia cyparissias L., and Verbascum lychnitis L., which were observed in 
two sites only over the entire department) or not adapted to wasteland habitat (e.g. Ranunculus ficaria L., Veronica hederifolia L., and Carpinus betulus L, which were found in numerous sites $(>100)$ in non-wasteland habitats). In fact, only four species observed in wastelands are considered endangered at a regional scale (Cardamine impatiens L.) or of floristic interest in

5 the region (Nepeta cataria L., Chondrilla juncea L., and Torilis nodosa (L.) Gaertn.) (CSRPN and DIREN Idf 2002), but all four were observed in at least three sites (up to 10 sites for Torilis nodosa).

Finally, 73 (20\%) observed species were naturalized species. Within sites, the fraction of naturalized species varied between 0 and $46 \%$, with a mean of $15 \%$. This proportion was not 10 significantly dependent on wasteland age $\left(r^{2}=0.009, P=0.86\right)$. Each naturalized species remained somewhat rare, being found on average at 7.5 of the 98 sites (vs. 11.3 for indigenous species); in addition, 27 of the 73 naturalized species were found in a single site. However, a number of naturalized species that are considered invasive by managers of green spaces were also found in a large number of wasteland sites. Five of the main invasive species in the

15 Greater Paris area, namely Buddleja davidii Franch., Solidago canadensis L., Ailanthus altissima (Mill.) Swingle, Robinia pseudoacacia L., and Reynoutria japonica Houtt. occurred respectively in 49, 21, 20, 20 and 18 of the 98 sites we inventoried. Senecio inaequidens DC., which is also considered invasive, had a lower occurrence (6/98), but was found almost exclusively in wastelands.

\section{Relationship between floristic, environmental, and geographic distances}

Regardless of site area, floristic distances were never significantly correlated with environmental distances (results not shown). In contrast, in the largest sites only $\left(>2500 \mathrm{~m}^{2}\right)$, floristic similarity among sites was significantly negatively correlated with geographic distance 
(Mantel statistics $r=0.214, P<0.001$, Figure 3); this remained true when the environmental distances among sites were accounted for (Mantel statistics $r=0.182, P=0.003$ ).

\section{$\underline{\text { Impact of urban structures on floristic interest }}$}

We examined the relationship between (1) the floristic interest of sites (Rich, Ind and Rar) and

5 (2) the significant variables of the ANCOVA and the proportion of each urbanization class within a radius of 200 meter around the sites. The results of the hierarchical partition are given Table 2.

\section{Species richness}

Site species richness depended exclusively on site area and age: large wastelands or wastelands

10 of intermediate age (4 to 13 years) had a higher richness than small or old ( $>21$ years) wastelands (Figure 4 and 5).

\section{Rarity}

Site rarity was influenced by season of inventory (rarity was highest in summer during which most of the plants flower, thus their detectability is at the maximum) and Land Use

15 Pattern in the site (e.g. rarer species on average in "open zones" than in "built zones" wastelands, Appendix A). The presence of collective or individual dwellings within a radius of $200 \mathrm{~m}$ around a site had a significant negative independent effect on species rarity. Inversely, the presence of water (WATE) within $200 \mathrm{~m}$ was significantly positively correlated with higher species rarity.

\section{Indigeneity}

The indigeneity of a site depended on its distance from the center of Paris, with higher indigeneity away from Paris. In contrast to rarity, the presence of individual dwellings (INDI) within $200 \mathrm{~m}$ of a site was positively correlated with the proportion of indigenous species. 


\section{Discussion}

We studied 98 wastelands sites in the Hauts-de-Seine department, one of the most densely populated areas in France, to document the significance of wastelands as reservoirs of floristic diversity in urban zones and to explore the factors controlling the diversity of wastelands. In

5 the following, we review the main characteristics of wasteland floristic interest in Hauts-deSeine and discuss the possible mechanisms underlying the observed patterns as well as the potential role of wastelands in the conservation of urban biodiversity.

\section{Characteristics of plant communities in urban wastelands}

Wastelands seem to be a relatively rich habitat of urban zones: their floristic richness

10 represents $58 \%$ of the total richness observed in the whole study area, which makes wastelands the richest habitat in the department (365 species among the 626 species recorded), followed by urban lawns (303 species) (Muratet 2006). This value is somewhat similar to that observed in a comparable study in Düsseldorf, where wasteland richness represented $51 \%$ of the total richness (277 among 550 species recorded in the whole city, Gödde and others 1995). Despite

15 high species richness, a substantial fraction of the observed species consisted of naturalized species $(20 \%)$, which is more than the department average of $17 \%$ (Student's t-Test $=-2.75$, pvalue $=0.006$ ). This may have important consequences in terms of conservation policies.

A large number of species observed in a majority of the wastelands were generally temperate, almost cosmopolitan species: Artemisia vulgaris L. (found in $81 \%$ of the sites),

20 Cirsium arvense (L.) Scop. (72\%), Plantago lanceolata L. (65\%), Picris hieracioides L. (63\%), Urtica dioica L. (59\%), Taraxacum campylodes G.E. Haglund (52\%), Calystegia sepium (L.) R.Br. (51\%), Rumex obtusifolius L. (50\%), and Buddleja davidii Franch. (50\%). These species are characterized by (1) perenniality, (2) high dispersal capacity and seed 
production, and (3) high nitrophily (average N Ellenberg index of 7, Ellenberg 1979). Cirsium arvense, Rumex obtusifolius and Buddleja davidii have also been mentioned by Godefroid and others (2006) among the most frequent species of wastelands in Brussels. On average, species that are considered invasive by managers were more frequent in wastelands habitat (e.g. $76 \%$

5 of sites harbored at least one of the six main invasive species (B. davidii, S. canadensis, A. altissima, $R$. pseudoacacia, $R$. japonica, and S. inaequidens) than in most other habitats of Hauts-de-Seine (on average $35 \%$ only of other sites were "invaded"). Wastelands have a similar level of invasibility than other highly disturbed habitats (i.e. edges of running water $(65 \%)$, wet thickets $(74 \%)$ or railway slopes $(78 \%))$ and could, similarly, play a major role in 10 invasion processes.

Wastelands also exhibited a large number of locally very rare species (17), i.e. species that were observed only once in the department. These species, because they are locally very rare and occupy temporary habitats, owe their maintenance through time to the ability to migrate among sites. Their maintenance in the department relies on the existence of networks of 15 wastelands, i.e. groups of geographically close wastelands that are connected through the existence of urban structures enabling gene flow (streets, parks, river banks...). In the wastelands of Hauts-de-Seine, we observed a single regionally protected species. The presence of such a rare species was unexpected because protected species generally grow in rare or declining habitats (such as marshes, calcareous lawns...) and are rarely observed in common, 20 human-made habitats.

Factors influencing the floristic interest of wasteland sites in a densely populated urban area

\section{Anthropogenic parameters}

We defined wastelands as sites where vegetation management had been temporarily abandoned, but not long enough for an identified natural habitat (e.g. a forest) to settle. 
Therefore, a large number of wastelands arise following destruction of buildings (BUILVAC) and are temporarily abandoned until a new project is undertaken. This transition state of wastelands in building and vacant areas makes them highly vulnerable and, in contrast to other wastelands in the department, they are generally rather young because of the rapid turn-over of 5 such habitats within cities (70\% of wastelands in BUILVAC were younger than 13 years). Wastelands in building sites and vacant areas were also the largest wasteland types $\left(4494 \mathrm{~m}^{2}\right.$ on average).

A significant number of wasteland sites, ranging from $12 \mathrm{~m}^{2}$ to $18260 \mathrm{~m}^{2}$, have also been observed in other classes of the land use pattern. Wastelands observed in open urban and rural 10 areas (OPENRUR) corresponded to green spaces that were less regularly managed than lawns. They were older on average than sites in building and vacant areas (44\% older than 21 years) and their floristic diversity was more likely to depend strongly on the intensity of management. Wasteland sites observed in the different types of built urban areas (activities, individual and collective dwellings, facilities, transports) corresponded to abandoned industrial plots or to 15 small interstices in the built matrix on which no urban projects were developed. These sites were significantly the smallest ones $\left(808 \mathrm{~m}^{2}\right.$ on average) and were highly isolated (because they were surrounded by construction), but they were stable in the long term ( $92 \%$ were older than 21 years). Finally, old wastelands (all older than 21 years) could also be observed in natural plots (water and wood), but they represented a minor fraction $(2 \%)$ of wasteland sites.

20 These wastelands were observed in the disturbed edge of natural zones.

Site age and area, which can be considered anthropogenic parameters because they are predominantly controlled by urban management, had a significant impact on the biodiversity of wastelands. The largest sites were also the richest ones (Figure 4), as found in similar studies (Davis and Glick 1978) and may be more resistant to potential disturbance than small sites 25 (Grumbine 1990). We also found a non-monotonous relationship between site age and 
richness, with a maximum floristic richness observed in sites of intermediate age (4 to 13 years, Figure 5). Old wastelands were significantly less diverse than sites of intermediate age. This observed maximum richness at intermediate age could be attributable to classical patterns of ecological succession, with transient high levels of diversity but establishment of a smaller

5 number of species in the stable communities resulting from the initial colonization/competition processes (Horn 1974). Alternatively, as most (70\%) old wastelands were situated in built urban areas, the urban matrix may isolate them from each other, thus preventing exchanges of species (via seeds for example) and resulting in lower levels of floristic diversity.

The proportion of indigenous species was found to be positively correlated with the distance

10 from the center of Paris, a correlate of urbanization intensity. This pattern was already observed in other cities (McDonnell and Pickett, 1990 and Maurer et al., 2000) and highlights the role of major communication routes and perturbations in the establishment of non-native species. The average percentage of aliens in central European cities is $13.7 \%$ higher than their representation in the total species pool available in the region, indicating a remarkable

15 concentration of aliens in urban areas (Pysek, 1998). The proportion of non-native species rises from $6 \%$ in nature preserves outside the city of Berlin to $25 \%$ in the suburbs to $54 \%$ in the most intensively urbanized central areas (Kowarik, 1995).

\section{Environmental parameters}

20 Unexpectedly, we did not find evidence of any effect of the environmental parameters (parent rock, exposition, slope, or geomorphology) on wasteland floristic interest and, accordingly, the floristic distance among sites was not significantly correlated with their environmental distance. This likely does not reflect an actual absence of environmental effects in urban areas, as these are unavoidable and have been observed by Godefroid and others (2006) in Brussels, 
example, the use of parent rock (not retained in the final model of ANOVA) to describe site environment might be inefficient because, in urban and industrial areas, the ground is usually covered with alien substrates from other geographical regions (e.g. railway ballast, mine spoil), with artificial substrates (e.g. slag), or with a mixture of artificial and natural substrates (e.g.

5 slag/clay) (Rebele 1994). In addition, site slope and light exposition were very homogeneous across studied wastelands, with more than $75 \%$ of sites having a slope $<1$ (i.e. no specific exposition). This is the result of strong urbanization, which tends to level all surfaces. Site geomorphology (hill, plain, valley etc...) may not have any effect on floristic interest in sites of such a fragmented landscape and may be relevant only in large natural landscapes. Finally, soil

10 type and especially soil fertilization frequently have a conspicuous role in floristic composition and diversity in urban context (Peet and others 1983). However, this parameter was so heterogeneous within a site that a much larger number of samples would have been required to adequately explore its influence.

15 Isolation by distance, migration among wasteland and non-wasteland sites

In large sites, we detected significant isolation by distance for floristic diversity, i.e. large neighboring sites were often floristically more similar than distant sites. This, together with the observed absence of environmental effects on floristic interest, suggests that migration of species among large sites might have a significant impact on local floristic composition, which

20 is influenced by the pool of available species in the neighborhood and their capacity to disperse/colonize. In contrast, small sites, which have a lower probability to receive propagules by chance and are often isolated by the matrix of buildings, are less influenced by the composition or surrounding sites.

The supply of species from non-wasteland sites likely influenced floristic interest in 25 wastelands as well. We have shown that the presence of water (rivers and ponds notably) 
within a radius of $200 \mathrm{~m}$ had a positive impact on the floristic rarity of a wasteland. Humid habitats are generally highly diverse and harbor many rare species of high conservation interest. In wastelands situated near water sites, we found Alnus incana (L.) Moench (that was observed in only four sites in the department (986 Sites), Alopecurus pratensis Mattf. (four

5 sites), Cardamine impatiens L. (four sites), Equisetum telmateia Ehrh. (three sites) and Stachys palustris L. (five sites).

In contrast, the presence of collective and individual dwellings around a site had a significant negative influence on floristic rarity. These findings have major consequences for management plans. They indicate, for example, that the establishment of dwelling districts will

10 certainly reduce the quality of neighboring wastelands and more generally of green lands. However, the presence of individual dwellings seemed to have a positive impact on the proportion of indigenous species in the wastelands around. This result is somewhat surprising, as small gardens surrounding houses were expected to host many exotic species for ornamental purpose. It may be that these cultivated exotic species remain "trapped" in the gardens, and that 15 meticulous gardening practices prevent the dispersal and establishment of exotic species considered as weeds (e.g. Conyza canadensis and C. sumatrensis, Artemisia annua ...)

\section{Conclusions}

Our study confirms that urban wastelands are a habitat of crucial importance in urban areas. Thanks to their large and homogeneous distribution in the department, they host a substantial 20 proportion of floristic diversity of cities and certainly play a key role in favoring exchanges among urban habitats. Thus, although the preservation of wastelands has little consequence for the conservation of rare species in the present case, our study shows that their maintenance is necessary to protect urban biodiversity as a whole because they favor connectivity among sites and provide a source of species to colonize vacant sites. Unfortunately, wastelands are one of 
the more threatened urban habitats due to urban intensification: for example, the total surface of building and vacant areas, which contain a large number of wastelands (Figure 2), has decreased by $24 \%$ in the last 20 years in Hauts-de-Seine.

In this work, we could not study whether the presence of wastelands has a positive impact 5 on the floristic diversity of other habitats in the department because we did not locate all wastelands and could not correlate the diversity at a given site with the presence/absence of wastelands in the neighborhood. However, we have shown that humid zones have a positive impact on the mean species rarity of wastelands, and it is highly likely that, in a symmetrical way, wastelands are beneficial to other habitats. Assessing the actual impact of wasteland sites

10 on the floristic diversity of other urban habitats will require further investigation; nonetheless our results suggest a number of simple actions that could be taken to favor the preservation of the floristic diversity in the Hauts-de-Seine. For example, the maintenance and the creation of large sites $\left(>2500 \mathrm{~m}^{2}\right)$ could favor species exchange among wastelands, lower the extinction risk of plant populations and provide seeds to colonize new sites. Note however that invasive

15 species were frequently found in wastelands, so highly connected sites could also act as relays to favor the spread of these species. The role of wastelands, a habitat submitted to frequent disturbance, in species invasion remains unclear. Additional information regarding abundance within sites is required to understand the dynamics of invasive species in these habitats. Finally, we also suggest that too rapid turnover should be avoided: waiting around ten years 20 before construction of new buildings would leave enough time for installation of highly diverse plant communities and for a maximum contribution to the floristic diversity of surrounding sites. 


\section{Acknowledgments}

Funding for this research was provided by the Conseil Général des Hauts-de-Seine. We thank Yoann Faivre for his help on the field, Gérard Arnal, Sébastien Filoche and Fabrice Perriat for their help in plant identification and three anonymous reviewers for helpful comments on an 5 earlier version of the manuscript. 


\section{References}

Conseil Scientifique Régional du Patrimoine Naturel (CSRPN IdF), Direction Régionale de l'Environnement d'Ile-de-France (DIREN IdF). 2002. Guide méthodologique pour la création de Zone Naturelle d'Intérêt Ecologique, Faunistique et Floristique (ZNIEFF) en Ilede-France. Direction Régionale de l'Environnement d'Ile-de-France, Cachan

Davis AM, Glick TF. 1978. Urban ecosystems and island biogeography. Environmental Conservation 5: 299-304

Ellenberg H. 1979. Indicator values of vascular plants in Central Europe. Scripta Geobotanica 9: 7-122

10 Gödde M, Richarz N, Walter B. 1995. Habitat conservation and the development in the city of Düsseldorf, Germany. In: Sukopp H, Numata M, Huber A, editors. Urban Ecology as the Basis of Urban Planning. The Hague: SPB Academic Publishers. p163-71.

Godefroid S, Monbaliu D, Koedam N. 2006. The role of soil and microclimatic variables in the distribution patterns of urban wasteland flora in Brussels, Belgium. Landscape Urban Plan in Press

Grumbine RE. 1990. Viable Populations, Reserve Size, and Federal Lands Management: A Critique. Conservation Biology 4: 127-34

Harrison C, Davies G. 2002. Conserving biodiversity that matters: practitioners' perspectives on brownfield development and urban nature conservation in London. J Environ Manage 65:95-108

Herbst H, Herbst V. 2006. The development of an evaluation method using a geographic information system to determine the importance of wasteland sites as urban wildlife areas. Landscape Urban Plan 77:178-195 
Horn HS. 1974. The ecology of secondary succession. Annu Rev Ecol SySt 5: 25-37

Hurtt GC, Pacala SW. 1995. The consequences of recruitment limitation: reconciling chance, history and competitive differences between plants. J Theor Biol 176:1-12

INSEE. 1999. National Institute for Statistics and Economic Studies. http://www.insee.fr

5 IAURIF. 2003. Institute for Planning and Development of the Paris Ile-de-France Region. http://www.iaurif.org

Kowarik I.1995. Time lags in biological invasions with regard to the success and failure of alien species. In P. Pysek, K. Prach, M. Rejmànek \& M. Wade (Eds.), Plant invasions:

General aspects and special problems. SPB Academic publishing, Amsterdam, pp. 15-38

10 MapInfo, MapInfo corporation 2004. MapInfo professional version 7.8

Maurer U, Peschel T, Schmitz S. 2000. The flora of selected urban land-use types in Berlin and Potsdam with regard to nature conservation in cities. Landscape Urban Plan 46:209-215

McDonnell, M., Pickett, S., 1990. Ecosystem structure and function along urban-rural gradients: An unexploited opportunity for ecology. Ecology 71, 1232-1237.

15 McNally R. 2002. Multiple regression and inference in ecology and conservation biology: further comments on identifying important predictor variables. Biodivers Conserv 11:13971401

Muratet A. 2006. Diversité végétale en milieu urbain. L'exemple des Hauts-de-Seine. PhDThesis. University of Paris VI. $121 \mathrm{p}$

20 Oksanen J, Kindt R, O’Hara RB. 2005. Vegan: Community Ecology Package. R package version 1.6-9.

Peet RK, Glenn-Lewin DC, Wolf JW. 1983. Prediction of man's impact on plant species diversity. In: Holzner W, Werger MJA, Ikusima I, editors. Man's impact on vegetation. The Hague: Dr W. Junk Publishers. p41-54. 
Pysek P. 1998. Alien and native species in Central European urban floras: A quantitative comparison. Journal of Biogeography 25: 155-63

R Development Core Team. 2005. R: A language and environment for statistical computing. R Foundation for Statistical Computing, Vienna

5 Rebele F. 1994. Urban ecology and special features of urban ecosystems. Global Ecol Biogeogr 4:173-187

Rexstad E, Burnham KP. 1991. User's guide for interactive program CAPTURE. Abundance estimation of closed animal populations. Colorado State University, Fort Collins, Colorado

Richardson DM, Pyšek P, Rejmánek M, Barbour MG, Panetta FD, West CJ. 2000.

10 Naturalization and invasion of alien plants: concepts and definitions. Diversity \& Distributions 6: 93

Sukopp H, Werner P. 1987. Développement de la faune et de la flore en territoire urbain. Strasbourg: Conseil de l'Europe. 61p.

Thioulouse J, Chessel D, Doledec S, Olivier J-M. 1997. ADE-4: a multivariate analysis and graphical display software. Stat Comput 7:75-83

Walsh C, MacNally R. 2004. hier.part: Hierarchical Partitioning. Version 1.0.: R package

Whitfield J. 2002. Neutrality versus the niche. Nature 417:480-481

Zerbe S, Maurer U, Schmitz S, Sukopp H. 2003. Biodiversity in Berlin and its potential for nature conservation. Landscape Urban Plan 62:139-148 
Appendix A. Abbreviations for Land Use Pattern classes (IAURIF 2003).

LAND USE PATTERNS

DEFINITIONS

\begin{tabular}{|c|c|c|}
\hline \multirow{5}{*}{ BUILT ZONES } & ACTI & Activities (Warehouses, Offices, Companies) \\
\hline & COLL & Collective dwelling \\
\hline & FACI & $\begin{array}{l}\text { Facilities (Education, Health, Administration, } \\
\text { Cemeteries, Electricity, Gas, Petroleum) }\end{array}$ \\
\hline & INDI & Individual dwelling \\
\hline & TRAN & Transport (Railways, Highways, Parking lots) \\
\hline \multirow{4}{*}{ OPEN ZONES } & BUILVAC & Building sites and Vacant urban \\
\hline & OPENRUR & $\begin{array}{l}\text { Open urban areas (Parks, Gardens, Sports, Camping, } \\
\text { Golf, Hippodrome) and rural (Truck farmings, } \\
\text { horticulture, orchards, breeding grounds, grounds and } \\
\text { pits) }\end{array}$ \\
\hline & WATE & Water \\
\hline & WOOD & Woods and forests \\
\hline
\end{tabular}


Figure 1. Location of the study area, the French department of Hauts-de-Seine (Built zones are in grey and Open zones in white, see Appendix A). Each point corresponds to a studied wasteland site.

5 Figure 2. Percentage of wastelands in each LUP type. Open urban areas are in grey, natural areas in white and built zones in black. Percentages were calculated over 88 sites only, because the LUP type was not available for 10 sites.

Figure 3. Floristic similarity (Jaccard index $=$ fraction of total species found in both sites)

10 between large sites $\left(>2580 \mathrm{~m}^{2}\right)$ as a function of geographic distance between sites.

Figure 4. Relationship between site richness and site area.

Figure 5. Average richness as a function of wasteland age. Error bars indicate standard 15 deviations. Significant differences ( $P \leq 0.05$, Tukey's test $)$ are indicated by different letters. 


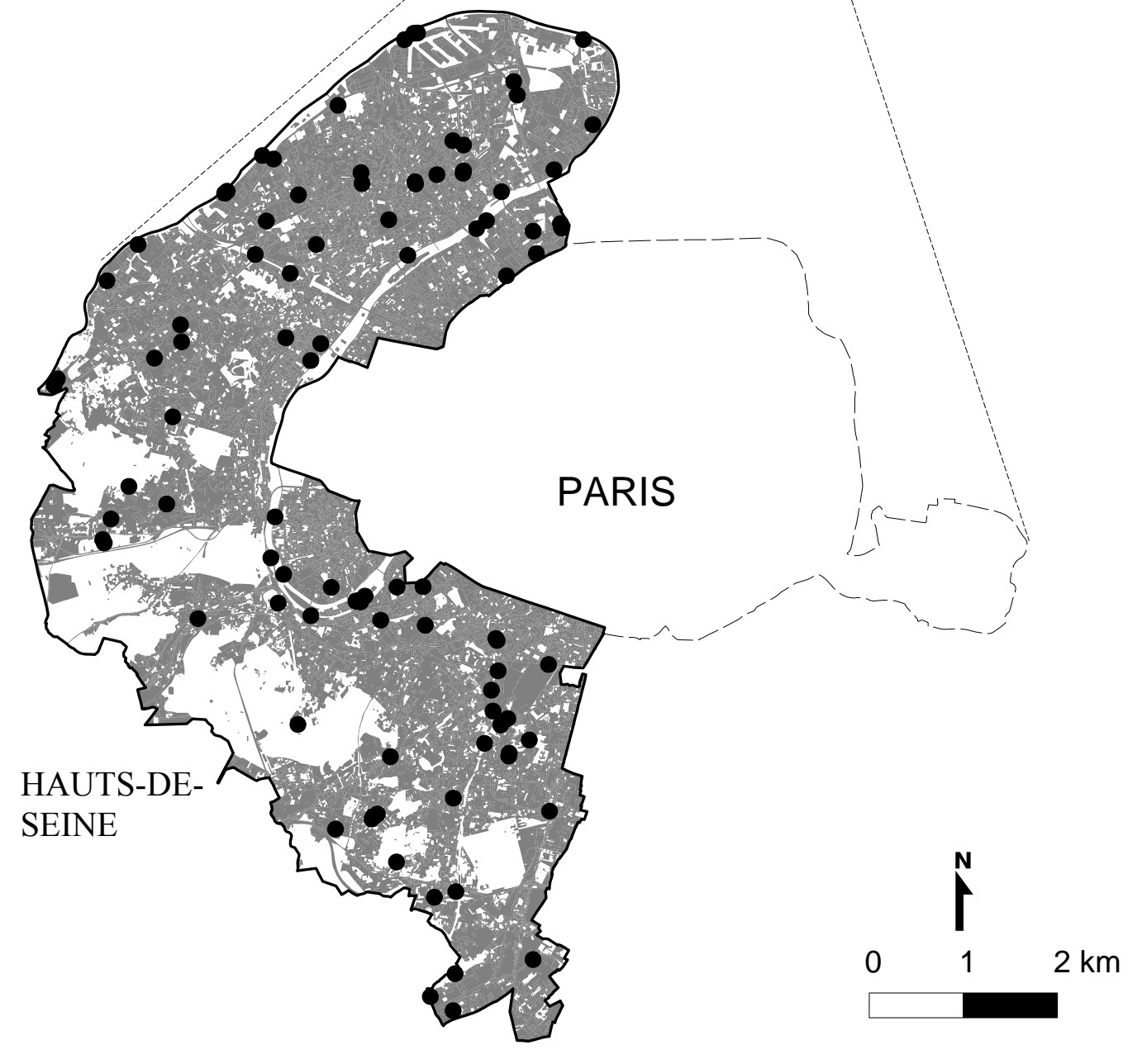

Figure 1 


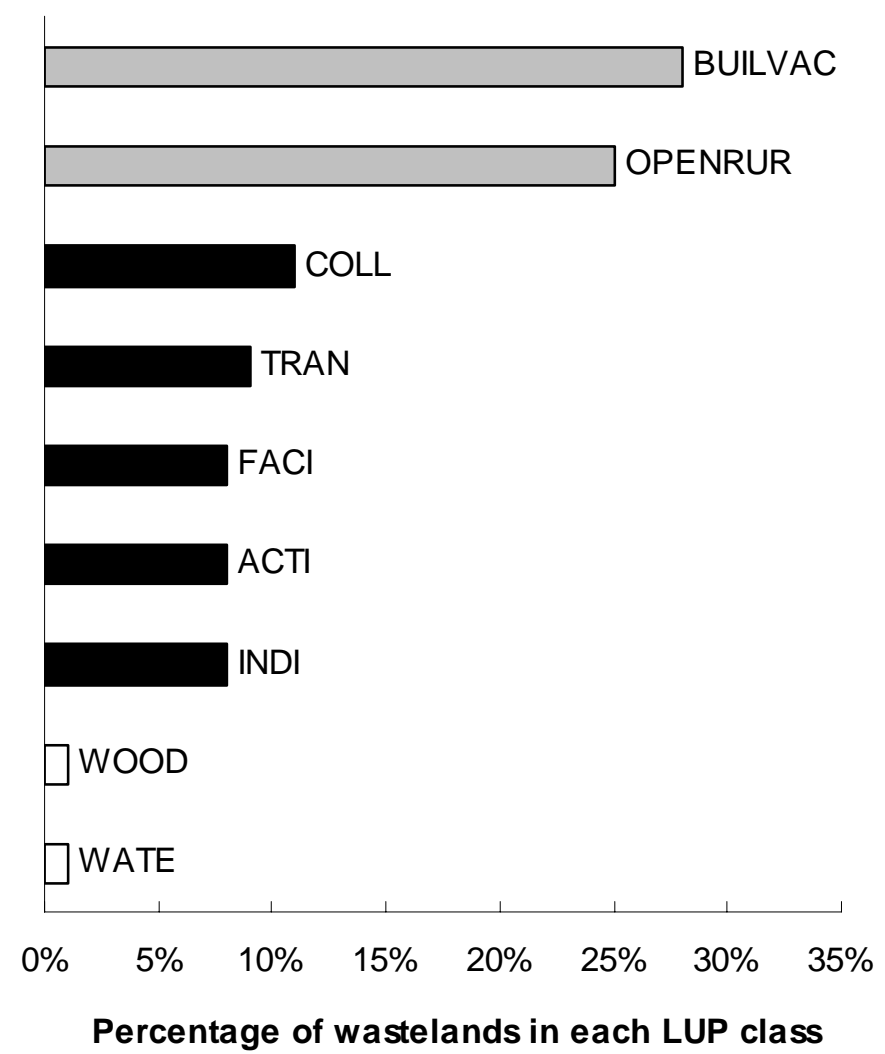

Figure 2 


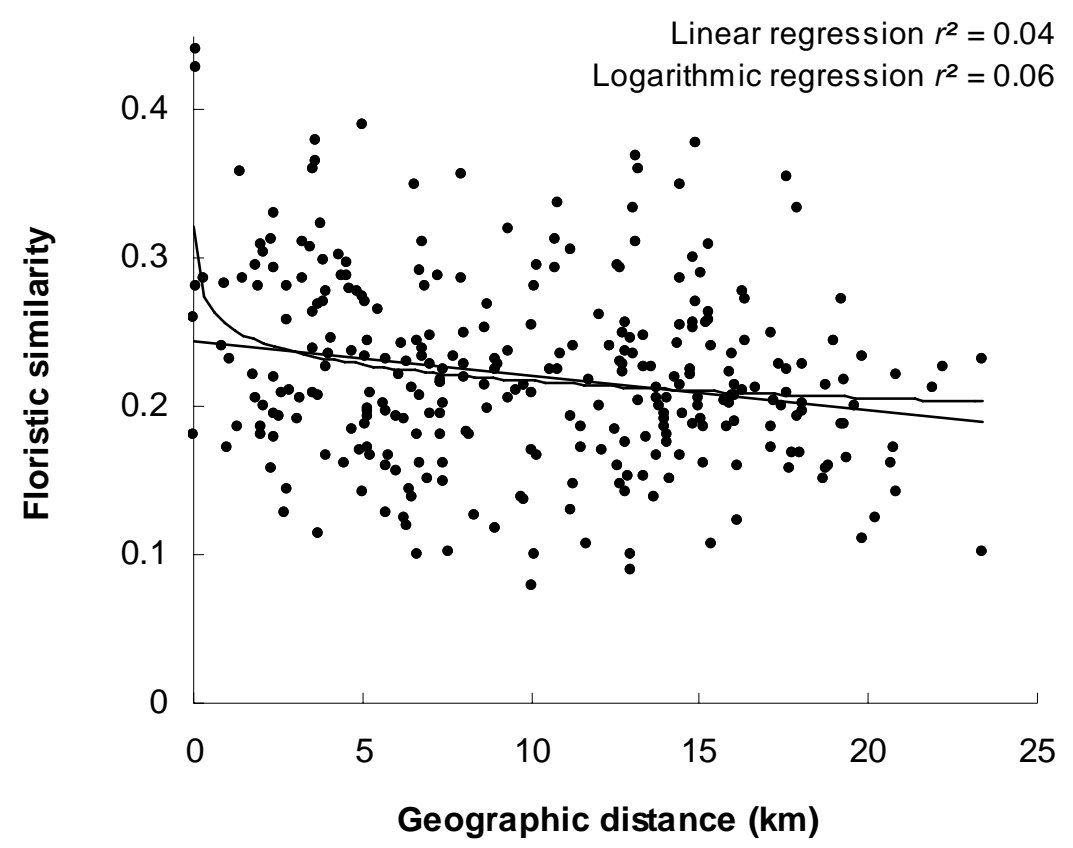

Figure 3 


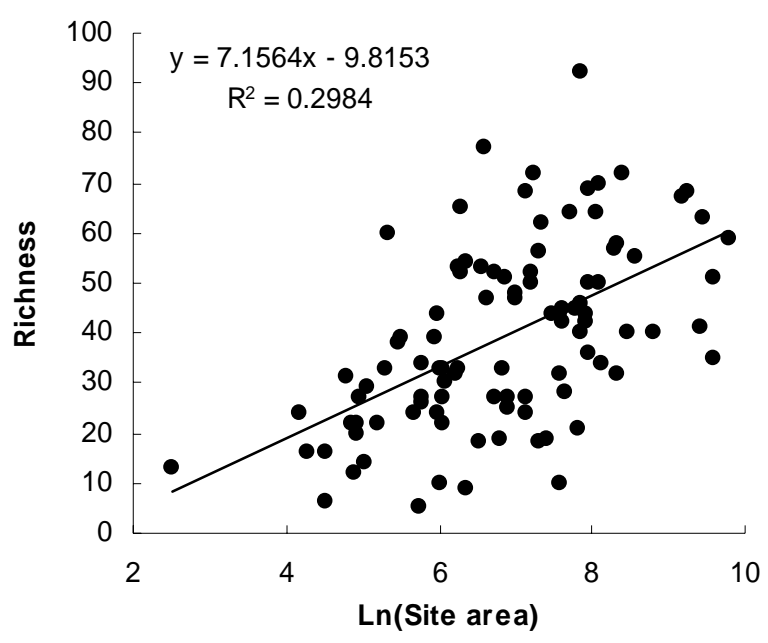

Figure 4 


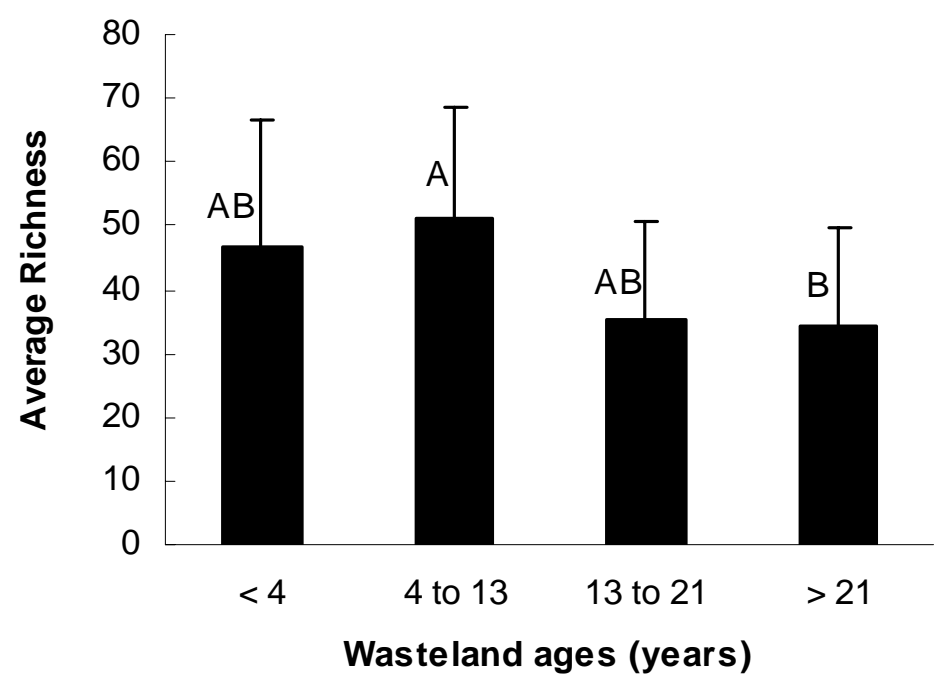

Figure 5 
Table 1. Age classes inferred from the Land Use Pattern (LUP) updates; number and average area of wasteland sites inventoried in each class. Significant differences in area $(P \leq 0.05$, Tukey's test) are indicated by different letters. Two groupings were performed so that each age class contained at least five inventories. Age could be inferred for 88 of 98 sites only, because

$5 \quad$ LUP type was not available for 10 wasteland sites.

Table 2. Results of a hierarchical partition on $r^{2}$ for independent contributions from 1000 randomizations of data matrices for potential explanation of the floristic interest of sites (Rich, Ind and Rar). Stars indicate significant contribution at the upper $95 \%$ confidence limit, The plus (respectively minus) sign indicates a positive (respectively negative) relationship. The 10 explanatory variables include the significant variables of the ANCOVA for each floristic interest parameter, plus the proportion of each urbanization class (Appendix A) within a radius of 200 meter around the sites. 
Table 1

\begin{tabular}{lccc}
\hline $\begin{array}{c}\text { AGE CLASSES } \\
\text { (years) }\end{array}$ & LUP CONDITIONS & $\begin{array}{c}\text { NUMBER OF } \\
\text { WASTELANDS }\end{array}$ & $\begin{array}{c}\text { MEAN AREA } \\
\left(\mathrm{m}^{2}\right)\end{array}$ \\
\hline Younger than 4 & In the same LUP class since 2003 & $1027(\mathrm{BC})$ \\
\hline Between 4 and 13 & In the same LUP class from 1994 to 1999 & 15 & $4053(\mathrm{AB})$ \\
\hline Between 13 and 21 & In the same LUP class from 1987 to 1990 & 5 & $6743(\mathrm{~A})$ \\
\hline Older than 21 & In the same LUP class since 1982 & 58 & $1261(\mathrm{C})$ \\
\hline
\end{tabular}


Table 2

\begin{tabular}{|c|c|c|c|}
\hline & RICHNESS & RARITY & INDIGENEITY \\
\hline PREDICTOR VARIABLES & & $\mathrm{r}^{2}$ VALUES & \\
\hline Area & $0.045^{*}+$ & 0.015 & \\
\hline Age & $0.054^{*}$ & & \\
\hline Season & & $0.025^{*}$ & \\
\hline LUP type & & $0.034^{*}$ & \\
\hline Distance to the center of Paris & & & $0.027^{*}+$ \\
\hline Activities (Warehouses, Offices, Companies) & 0.006 & 0.007 & 0.004 \\
\hline Building sites and Vacant urban & 0.007 & 0.010 & 0.001 \\
\hline Collective dwelling & 0.006 & $0.021^{*}-$ & 0.011 \\
\hline Facilities (Education, Health, Administration, Cemeteries...) & 0.004 & 0.009 & 0.004 \\
\hline Individual dwelling & 0.011 & $0.029^{*}-$ & $0.022^{*}-$ \\
\hline Transport (Railways, Highways, Parking lots) & 0.003 & 0.008 & 0.015 \\
\hline Water & 0.005 & $0.052^{*}+$ & 0.012 \\
\hline Woods and forests & 0.009 & 0.008 & 0.016 \\
\hline Open urban and rural areas & 0.013 & 0.013 & 0.016 \\
\hline
\end{tabular}

